\title{
Analisis Faktor Eksploratori Konstruk Risiko Online
}

\author{
Amia Luthfia ${ }^{1 *}$, Pinckey Triputra ${ }^{2}$, Hendriyani $^{3}$, Sari Ramadanty $^{4}$ \\ ${ }^{1,4}$ Bina Nusantara University, J1. K. H. Syahdan No. 9, Jakarta 11480, Indonesia \\ ${ }^{2,3}$ Universitas Indonesia, Kampus UI Depok, Depok 164242, Indonesia \\ amialuthfia@gmail.com
}

\begin{abstract}
Risks and disadvantages of the Internet usage by children and adolescents is called online risk. Online risk is a new concept thus the definition of which is debatable. In addition, the classification of risk is based on the coding results of the children's responses from a qualitative research. This research aims to find the dimensions for online risk variable and build online risk scale for similar research in Indonesia.

This study examines the validity of online risk constructs and explores how many factors were formed by using Exploratory Factor Analysis. Factor extraction method used in this research is Maximum Likelihood (ML) with Varimax factor rotation. This study uses online survey www.surveymonkey.com to obtain responses from respondents. Respondents in this study were 161 adolescents aged 13-18 years who study and live in Jakarta.

The exploratory factor analysis shows that all 33 item statements are justify as indicator as they have significant anti-image correlation coefficient. The result of extraction and rotation are 6 factors with cumulative variance value of $69.557 \%$. This score is quite good as it explained more than $50 \%$ total variant. These six factors can be used as dimensions of the online risk variable. The dimensions of the online risk variable are (1) Risky behavior; (2) Misleading values \& information; (3) Pornography; (4) Target of risky conduct; (5) Cyberbullying and harassment; (6) Strangers.
\end{abstract}

Keywords: Exploratory Factor Analysis, Online Risk, Internet, Adolescents, Internet Effect, Online Risk Scale

\begin{abstract}
Abstrak
Semua risiko dan sisi merugikan sebagai konsekuensi dari penggunaan Internet dan eksplorasi anak dan remaja di Internet dinyatakan sebagai risiko online. Risiko online merupakan sebuah konstruk yang sifatnya baru dibangun dan definisi dari konsep ini masih diperdebatkan. Selain itu, pengelompokkan risiko (dimensi) dari konsep ini didasarkan pada hasil koding dari respon anak-anak dari penelitian kualitatif. Maka, penelitian ini bertujuan untuk menemukan dimensi-dimensi untuk variabel risiko online dan membangun skala risiko online untuk penelitian sejenis di Indonesia.

Penelitian ini menguji validitas konstruk risiko online dan menggali berapa faktor yang terbentuk dari konstruk risiko online dengan dengan menggunakan Exploratory Factor Analysis. Metode ekstraksi faktor yang digunakan pada penelitian ini adalah Maximum Likelihood (ML) dengan rotasi faktor Varimax. Penelitian ini menggunakan survei online www.surveymonkey.com untuk memperoleh respon dari responden. Responden pada penelitian ini sebanyak 161 remaja DKI Jakarta berusia 13-18 tahun.

Analisis faktor eksploratori menunjukkan hasil bahwa keseluruhan 33 item layak untuk dijadikan indikator karena memiliki koefisien korelasi anti-image yang baik. Dari ekstraksi dan rotasi faktor dihasilkan 6 faktor dengan nilai kumulatif varian sebesar $69.557 \%$, nilai ini cukup baik karena total varian yang dapat dijelaskan melebihi 50\% varian. Enam faktor yang dihasilkan ini dapat dijadikan dimensi dari variabel risiko online. Maka, dimensi dari variabel risiko online adalah (1) Tindakan berisiko; (2) Nilai \& informasi menyesatkan; (3) Pornografi; (4) Target dari tindakan berisiko; (5) Perundungan dan pelecehan; (6) Orang tidak dikenal.
\end{abstract}

Kata kunci: Analisis Faktor Eksploratori, Risiko Online, Internet, Remaja, Efek Internet, Skala Risiko Online

Copyright $\odot 2018$ Ikatan Sarjana Komunikasi Indonesia. All rights reserved 


\section{PENDAHULUAN}

Internet telah menjadi bagian integral bagi kehidupan manusia di era digital saat ini. Semakin banyak orang yang sangat tergantung pada Internet dalam menjalani kehidupannya sehari-hari, seperti mencari informasi, berkomunikasi dengan rekan dan keluarga, mencari moda transportasi, membeli barang kebutuhan sehari-hari, bermain games dan mencari hiburan lainnya, bahkan menjalankan bisnis online.

Meningkatnya aktivitas ini sejalan dengan semakin meningkatnya ketersediaan koneksi Internet di berbagai negara, termasuk di Indonesia. Kualitas sambungan yang semakin luas dan cepat dan tersedianya berbagai peranti mobile yang memudahkan setiap orang untuk tersambung dengan Internet dimana saja dan kapan saja.

Dari berbagai studi yang telah dilakukan tentang penggunaan Internet pada remaja, menunjukkan hasil bahwa Internet bagai pedang bermata dua, di satu sisi bermanfaat sebagai sumber informasi (Livingstone, 2009; Qomariyah, 2009); media dakwah dan belajar (Setiawan, 2011); bermanfaat dalam proses belajar mengajar (Bosch, 2009). Tapi di sisi lain dapat merugikan (Cho \& Cheon, 2005), seperti turunnya prestasi belajar (Karman, 2012); kontak dengan orang tak dikenal (Juditha, 2011), mengunjungi situs pornografi (Qomariyah, 2009), kecanduan (Cho \&Cheon, 2005; Leung \& Lee, 2011) bahkan kematian (Livingstone, 2009; Steiner-Adair \& Barker, 2013).

Studi-studi di atas menunjukkan bahwa Internet seperti media lainnya, yaitu memberikan efek positif dan efek negatif. Salah satu efek negatif dari penggunaan Internet adalah dapat membuat remaja mengunjungi situs porno dengan sengaja. Memang, aktivitas mengunjungi situs porno hanya 10\% dibandingkan aktivitas berinternet yang lain, tapi 10\% ini dilakukan dengan sengaja (Sonia Livingstone, 2011). Bagaimana yang terterpa konten negatif lainnya tidak dengan sengaja? Atau bagaimana dengan tindakan berisiko yang tidak dipahami dan tidak disadari berbahaya oleh remaja? Untuk mengetahui itu semua perlu dibangun konsep yang ajeg yang dapat mengukur berbagai risiko dari penggunaan Internet pada anak dan remaja.

Semua risiko atau sisi merugikan sebagai konsekuensi dari penggunaan Internet dan eksplorasi anak dan remaja di Internet dinyatakan oleh Sonia Livingstone (2011) sebagai risiko online. Risiko online meliputi: kontak dengan pedofili("grooming”); terpapar konten kekerasan, kekerasan seksual, materi rasism, iklan; mengalami cyberbullying, penguntitan, pelecehan, perjudian, penipuan; melakukan tindakan yang melukai diri seperti bunuh diri, bulimia, anorexia, dan lain-lain. Meskipun masih diperdebatkan, risiko online (online risks) secara umum didefinisikan sebagai satu set pengalaman heterogen yang sengaja maupun tidak sengaja yang dapat membahayakan pengguna internet: meliputi terpapar pornografi, menyakiti diri, kekerasan, rasisme atau konten kebencian, kontak dengan pelaku pedofili atau pelecehan, cyberbullying, "happy slapping” atau pelanggaran privasi (Staksrud \& Livingstone, 2009).

Risiko online merupakan sebuah konstruk yang sifatnya baru dibangun dan diakui oleh Livingstone definisi dari konsep ini masih diperdebatkan. Oleh karenanya, pembangunan konstruk menuju pemahaman dan pengujian yang empiris maka mutlak diperlukan. Selain itu, klasifikasi risiko online yang dilakukan oleh Livingstone et al (2014) dan Hasebrink (2009), didasarkan pada hasil koding dari respon anak-anak pada penelitian kualitatif mereka di tahun 2010 (lihat S. Livingstone, Kirwil, Ponte, \& Staksrud, 2014).

Oleh karena klasifikasi risiko online yang belum melalui uji statistik, maka penelitian ini mengklasifikasikan lagi dimensi-dimensi dari risiko online berdasarkan muatan faktor item-item dari skala risiko online dengan menggunakan Exploratory Factor Analysis (EFA). Tujuan dari EFA adalah untuk menemukan struktur laten dari variabel teramati dengan mengungkap faktor-faktor yang sama dan dimensi-dimensi yang tersembunyi yang dapat mempengaruhi variabel terukur (Park, Dailey, \& Lemus, 2002). Selain itu dimensi dan indikator dari konsep ini perlu diujikan lagi kecocokannya untuk konteks Indonesia. Maka, penelitian ini bertujuan untuk menemukan dimensi-dimensi untuk variabel risiko online dan membangun skala risiko online untuk penelitian di Indonesia.

\section{KERANGKA TEORITIS}

Sebagai sebentuk konsep, ide atau gagasan, istilah (terminologi) risiko online (online risks) pertama kali diperkenalkan oleh Staksrud dan Livingstone (2009) dalam publikasi yang berjudul Children and Online Risks. Konsep risiko online yang dikemukakan oleh Staksrud dan Livingstone (2009) ini merujuk dari tulisan Beck $(1986 ; 2005)$ seorang teoritisi sosial yang banyak menulis tentang 'risk society' dan definisi risiko yang dikemukakan oleh Reyna dan Farley (2006). Beck (1986; 2005) menyatakan "risk may be defined as a systematic way of dealing with the hazards and insecurities induced and introduced by modernization itself." Beck lebih menekankan pada bagaimana masyarakat dengan cara sistematis menghadapi berbagai bahaya yang mengancam. Bahaya dan rasa tidak aman itu sendiri pada saat ini tidak hanya berasal dari bahaya alami seperti bencana alam, tapi lebih banyak karena hasil perkembangan tekno-ekonomi. 
Livingstone (2013) lalu merujuk juga dari Smillie and Blissett (2010) yang menyatakan bahwa risiko dapat dibedakan menjadi 'natural hazards' dan 'technological hazards' yang lebih menekankan pada upaya antisipasi dan mitigasi dari berbagai potensi bahaya. Risiko online termasuk pada kategori technological hazards dan merupakan bahaya yang dapat diantisipasi dengan merekayasa lingkungan sosial termasuk merancang bagaimana meresponnya bila terjadi kerugian secara fisik atau mental setelah suatu peristiwa online terjadi. Faktor-faktor yang dapat membahayakan antara lain berupa fitur online, manusia, aktivitas, peristiwa sebagai aspek di dalam lingkungan online yang dapat meningkatkan risiko merusak / melukai anak dan remaja (Livingstone, Mascheroni, \& Staksrud, 2015).

Berdasarkan literatur dan penelitian yang menelaah tentang risiko online, diperoleh beberapa definisi tentang risiko online, yaitu:

1. Risiko online adalah satu set pengalaman heterogen yang sengaja maupun tidak sengaja yang dapat membahayakan pengguna internet. "A heterogeneous set of intended and unintended experiences which increase the likelihood of harm to the Internet user" (Staksrud \& Livingstone, 2009; Livingstone et.al, 2011).

2. Risiko online merupakan berbagai aspek negatif dari penggunaan Internet. "Negative aspects of Internet use "( Livingstone \& Helsper, 2013).

3. Risiko online sebagai hasil transaksional dari mengakses, menggunakan Internet, juga hasil dari peran anak dan motif komunikasi yang mengarah pada konsekuensi negatif. "As a transactional result of access, usage, the child's role, and underlying communicative motives leading to negative consequences" (Hasebrink, Livingstone, Haddon, \& Olafsson, 2009).

4. Risiko online merupakan faktor-faktor yang berupa fitur online, manusia, aktivitas, peristiwa di dalam lingkungan online yang dapat meningkatkan risiko yang merusak / melukai anak dan remaja (Livingstone, Mascheroni, Staksrud, 2015).

Risiko online ini lalu dibedakan menjadi (1) resiko konten (content risks), yaitu anak tidak diperkenankan sebagai penerima pesan yang tidak sesuai untuk usianya; (2) resiko kontak (contact risks), yaitu anak-anak dalam kelompok atau personal yang berpartisipasi dalam komunikasi yang beresiko; (3) tindakan beresiko (conduct risks) yaitu anak-anak yang bertindak sendiri untuk berkontribusi membuat konten beresiko atau kontak beresiko (Staksrud \& Livingstone, 2009).

Selanjutnya, risiko-risiko tersebut dapat diklasifikasikan berdasarkan motivasi orang-orang (sumber/produsen) yang mengawali / membuat komunikasi dan informasi online. Lebih detilnya, klasifikasi ini digambarkan oleh bagan yang dibuat oleh Hasebrink et al. (2009) berikut ini.

Tabel 1. Klasifikasi Risiko Online pada Anak

\begin{tabular}{|c|c|c|c|c|}
\hline & Komersial & Agresif & Seksual & Nilai \\
\hline $\begin{array}{l}\text { Content-anak sebagai } \\
\text { penerima }\end{array}$ & Iklan, spam, sponsor & $\begin{array}{l}\text { Kekerasan/ } \\
\text { Konten kebencian }\end{array}$ & $\begin{array}{l}\text { Pornografi } \\
\text { / konten tidak pantas }\end{array}$ & $\begin{array}{l}\text { Rasisme / konten } \\
\text { menyesatkan }\end{array}$ \\
\hline $\begin{array}{l}\text { Contact-anak sebagai } \\
\text { partisipan }\end{array}$ & $\begin{array}{l}\text { Tracking/ } \\
\text { Memper-oleh info } \\
\text { personal }\end{array}$ & $\begin{array}{l}\text { Mengalami perundung- } \\
\text { an, pelecehan }\end{array}$ & $\begin{array}{l}\text { Bertemu dengan orang } \\
\text { tak dikenal }\end{array}$ & $\begin{array}{l}\text { Melukai diri sendiri, } \\
\text { bujukan }\end{array}$ \\
\hline $\begin{array}{l}\text { Conduct-anak } \\
\text { sebagai pelaku }\end{array}$ & $\begin{array}{l}\text { Berjudi, } \\
\text { hacking }\end{array}$ & $\begin{array}{l}\text { Melakukan } \\
\text { Perundung-an /pelecehan }\end{array}$ & $\begin{array}{l}\text { Mencipta } \\
\text { kan / } \\
\text { mengung- } \\
\text { gah materi } \\
\text { pornografi }\end{array}$ & $\begin{array}{l}\text { Menyajikan info menyesat- } \\
\text { kan }\end{array}$ \\
\hline
\end{tabular}

Sumber: (Hasebrink, Livingstone, Haddon, \& Olafsson, 2009)

Berbeda dengan Hasebrink et al. (2009), Leung \& Lee, (2011) mengelompokkan resiko-resiko online tersebut menjadi tiga, yaitu: (a) sebagai target dari pelecehan (harassment); (b) privacy exposure; (c) konsumsi konten pornografi dan kekerasan. Pelecehan internet adalah tindakan yang jelas bermaksud jahat untuk melakukan agresi terhadap seseorang di Internet. Tindakannya dapat berbentuk pelecehan yang disengaja atau mempermalukan seseorang atau membuat komentar kasar/buruk/menjijikkan kepada seseorang ketika online (Ybarra, Diener-West, \& Leaf, 2007). Privacy exposure mengacu pada ketidakmampuan untuk mengontrol informasi tentang diri sendiri melalui Internet terutama mengenai siapa yang dapat mengakses informasi tersebut. Livingstone dan Helsper (2007) menemukan bahwa membuat teman online dapat dikategorikan sebagai perilaku berisiko, terutama ketika ini menyebabkan pertemuan offline, seperti memiliki memberikan informasi pribadi (seperti alamat email, nomor telepon, alamat rumah, dan informasi kartu kredit) secara online (Leung, 2014). 


\section{METODOLOGI}

Pengembangan skala risiko online ini dimulai dengan menggunakan daftar jenis risiko online dari hasil penelitian kualitatif Livingstone et al (2014). Dari daftar jenis risiko online tersebut peneliti merancang menjadi 33 indikator untuk mengukur konstruk risiko online. Penelitian ini menggunakan survei online www.surveymonkey.com untuk memperoleh respon dari responden.

Responden adalah 161 remaja usia 13-18 tahun dengan kriteria: (1) tinggal dan bersekolah di DKI Jakarta; (2) terdaftar sebagai siswa di salah satu sekolah di wilayah DKI Jakarta (3) menggunakan Internet. Responden diminta untuk mengisi berkas online yang disebar melalui surat elektronik dan instant messaging.

Penelitian ini pada dasarnya berusaha untuk menguji validitas konstruk risiko online dan menggali berapa faktor yang terbentuk dari konstruk risiko online dengan dengan menggunakan Exploratory Factor Analysis. Pengujian ini bertujuan untuk membangun skala risiko online berdasarkan data empiris hasil survei. Exploratory factor analysis adalah teknik statistik multivariat yang digunakan untuk mengekstraksi indikator-indikator dari risiko online. Setiap indikator diranking berdasarkan persentase tertinggi dari variasi yang dihitung.

Metode ekstraksi faktor yang digunakan adalah Maximum Likelihood (ML) dengan rotasi faktor Varimax. Dipilihnya metode ekstraksi Maximum Likelihood karena metode ini memberikan hasil uji yang signifikan untuk menentukan jumlah faktor yang tepat untuk sebuah variabel terukur. Rotasi faktor Varimax dipilih karena metode rotasi ini membuat faktor-faktor saling independen (Park et al., 2002).

Indikator dan dimensi untuk pembuatan skala risiko online ini merujuk pada item dan tiga kategori risiko online yang dikemukakan oleh Livingstone et al (2014) dan Hasebrink (2008). Item pertanyaan/pernyataan dikelompokkan menjadi 3 kelompok, yaitu kelompok content risk, kelompok contact risk, kelompok conduct risk.

Responden diminta menjawab pernyataan, seperti: "Saya melihat konten pornografi kekerasan" dan responden memberi respon dengan jawaban dari 5 skala Likert "selalu; sering; kadang-kadang; jarang; tidak pernah" dimana respon "selalu" diberi skor 5 dan respon "tidak pernah" diberi skor 1.

\section{Pemilihan Indikator yang Layak}

\section{HASIL DAN DISKUSI}

Tahap ini adalah tahap awal dari proses analisis faktor. Pada tahap awal ini dilakukan dua proses yaitu proses pertama adalah melihat skor Keiser-Meyers-Oklin (KMO) Measure of Sampling Adequacy, yang digunakan untuk melihat seberapa cocok data yang ada untuk dilakukan analisis faktor. Bila skor KMO antara 0.8 dan 1 menunjukkan sampel memadai. Proses kedua adalah melihat nilai Barlett Test of Sphericity, yang digunakan untuk mengetahui apakah ada korelasi signifikan antar indikator. Bila koefisien anti-image korelasinya di atas 0.7 , maka indikator tersebut layak untuk dianalisis faktor.

Skor KMO pada penelitian ini sebesar 0.930 dengan taraf signifikansi 0.000 , yang berarti sampel yang digunakan memadai untuk dianalisis faktor. Tabel berikut menunjukkan bahwa seluruh indikator layak untuk dianalisis faktor karena mempunyai koefisien korelasi anti-image lebih besar dari 0.5.

Tabel 2. Koefisien Korelasi Anti-Image

\begin{tabular}{lrll}
\hline Indikator & Skor & Indikator & Skor \\
\hline Content 1 & 0.884 & Contact 5 & 0.963 \\
Content 2 & 0.893 & Contact 6 & 0.936 \\
Content 3 & 0.941 & Contact 7 & 0.955 \\
Content 4 & 0.910 & Contact 8 & 0.953 \\
Content 5 & 0.917 & Contact 9 & 0.952 \\
Content 6 & 0.886 & Conduct 1 & 0.941 \\
Content 7 & 0.914 & Conduct 2 & 0.939 \\
Content 8 & 0.905 & Conduct 3 & 0.955 \\
Content 9 & 0.930 & Conduct 4 & 0.930 \\
Content 10 & 0.952 & Conduct 5 & 0.937 \\
Content 11 & 0.935 & Conduct 6 & 0.926 \\
Content 12 & 0.911 & Conduct 7 & 0.956 \\
Contact 1 & 0.908 & Conduct 8 & 0.905 \\
Contact 2 & 0.832 & Conduct 9 & 0.926 \\
Contact 3 & 0.961 & Conduct 10 & 0.897 \\
Contact 4 & 0.937 & Conduct 1 & 0.969 \\
& & Conduct 12 & 0.905 \\
& & & \\
\hline
\end{tabular}




\section{Ekstraksi dan Rotasi Faktor}

Ekstraksi faktor dilakukan terhadap semua indikator yaitu sebanyak 33 indikator yang diekstraksi. Berdasarkan tabel 3, terdapat 6 faktor dengan nilai kumulatif varians sebesar $69.557 \%$, nilai ini cukup baik karena total varians yang dapat dijelaskan melebih 50\%. Sayangnya, $47.485 \%$ varians dijelaskan hanya oleh faktor 1, faktor lainnya hanya memperoleh persentase varians kurang dari $10 \%$.

Tabel 3. Varians Total yang Dijelaskan

\begin{tabular}{cccc}
\hline Faktor & Total & \% Varians & \% Kumulatif \\
\hline 1 & 15.670 & 47.485 & 47.485 \\
2 & 2.151 & 6.520 & 54.004 \\
3 & 1.402 & 4.248 & 58.252 \\
4 & 1.345 & 4.077 & 62.329 \\
5 & 1.243 & 3.767 & 66.096 \\
6 & 1.142 & 3.461 & 69.557 \\
\hline
\end{tabular}

Rotasi faktor dilakukan untuk memaksimalkan pengelompokkan indikator ke dalam dimensi-dimensi. Metode rotasi faktor Varimax yang digunakan dapat memaksimalkan jumlah varians dalam muatan faktor. Hasil rotasi dengan metode Varimax ini menghasilkan muatan-muatan faktor yang dijelaskan pada Tabel 4 di halaman terakhir dari artikel ini.

Berdasarkan hasil rotasi faktor, indikator dikelompokkan menjadi 6 kelompok faktor berdasarkan muatan-muatan faktornya. Padahal penelitian-penelitian yang dilakukan oleh Livingstone dan peneliti lain, indikator-indikator tersebut dikelompokkan menjadi tiga kelompok yaitu content risk, contact risk dan contact risk. Hasil ini menjadikan pengelompokan indikator risiko online yang dilakukan oleh Livingstone (2014) dan Hasebrink (2009) harus disesuaikan untuk konteks Indonesia yaitu menjadi 6 kelompok. Sehingga konstruk risiko online memiliki 6 dimensi.

Terdapat 11 indikator yang berada dalam 2 atau lebih kelompok faktor yang berbeda. Sebelas indikator tersebut adalah content 3 , content 5 , contact 4 , contact 5 , conduct 4 , conduct 6 , conduct 7 , conduct 8 , conduct 10, conduct 11 dan conduct 12. Indikator content 3 memiliki muatan faktor 0.595 berada di kelompok faktor 3 dan muatan faktor 0.469 di kelompok muatan faktor 2. Berdasarkan nilai muatan faktor dari content 3 tersebut, maka dipilih muatan faktor yang nilainya lebih tinggi yaitu yang berada di kelompok faktor 3. Demikian juga untuk indikator-indikator lainnya yang memiliki dua muatan faktor, kelompok faktor yang dipilih adalah yang memiliki muatan faktor yang lebih besar nilainya (lihat Tabel 4).

\section{Penamaan Faktor}

Penamaan faktor diberikan berdasarkan pengelompokan indikator yang ditunjukkan oleh muatan faktor dari setiap indikator. Pada penelitian ini, keenam faktor tersebut diberi nama: (1) Tindakan berisiko; (2) Nilai \& informasi menyesatkan; (3) Pornografi; (4) Target dari tindakan berisiko; (5) Perundungan dan pelecehan; dan (6) Orang tidak dikenal. Keenam nama faktor tersebut menjadi dimensi dari konstruk risiko online. Tabel 5 berikut ini menjabarkan setiap dimensi dan indikator-indikatornya.

Tabel 5. Dimensi dan indikator dari Konstruk Risiko Online

\begin{tabular}{|c|c|}
\hline $\begin{array}{c}\text { Dimensi } \\
\text { Risiko Online }\end{array}$ & $\begin{array}{c}\text { Indikator "Pengalaman / aktivitas saya ketika } \\
\text { berinternet..." }\end{array}$ \\
\hline $\begin{array}{l}\text { Faktor 1: } \\
\text { Tindakan } \\
\text { berisiko }\end{array}$ & $\begin{array}{c}\text { - Berpose seronok / mesum } \\
\text { - Berpura-pura menjadi orang lain } \\
\text { - Kontak dengan pedofili } \\
\text { - Kontak dengan orang yang memalsukan } \\
\text { identitas diri } \\
\text { - Kontak dengan orang yang mengajarkan } \\
\text { terorisme / ajaran sesat } \\
\text { - Kontak dengan orang yang membuntuti diri } \\
\text { - Tertipu membeli barang } \\
\text { - Berpose dengan pakaian minim } \\
\text { - Berpose intim dengan orang lain } \\
\text { - Mengirim foto/video diri pada orang tak } \\
\text { dikenal } \\
\text { - Membuat dan menyebar berita bohong }\end{array}$ \\
\hline
\end{tabular}




\begin{tabular}{|c|c|}
\hline & $\begin{array}{c}\text { - Memberi informasi pribadi pada orang tak } \\
\text { dikenal } \\
\text { - } \text { Bermain judi online }\end{array}$ \\
\hline $\begin{array}{l}\text { Faktor 2: } \\
\text { Nilai atau } \\
\text { informasi } \\
\text { menyesatkan }\end{array}$ & $\begin{array}{l}\text { - Melihat/membaca konten rasisme atau } \\
\text { kebencian } \\
\text { - Melihat/membaca konten kekerasan } \\
\text { - Melihat/membaca konten narkotika atau } \\
\text { miras } \\
\text { - Melihat/membaca konten perjudian / money } \\
\text { game } \\
\text { - Melihat/membaca konten bunuh diri / } \\
\text { menyakiti diri }\end{array}$ \\
\hline $\begin{array}{l}\text { Faktor 3: } \\
\text { Pornografi }\end{array}$ & $\begin{array}{l}\text { - } \text { Terterpa konten pornografi } \\
\text { - Mencari/menikmati konten pornografi } \\
\text { - Melihat/membaca konten pornografi } \\
\text { - kekerasan } \\
\text { - Menerima pesan / konten mesum } \\
\text { - } \text { Berbagi konten porno (sexting) }\end{array}$ \\
\hline $\begin{array}{l}\text { Faktor 4: } \\
\text { Target dari } \\
\text { tindakan } \\
\text { berisiko }\end{array}$ & $\begin{array}{l}\text { - Menerima pesan melecehkan / tidak } \\
\text { menyenangkan } \\
\text { - Menerima gosip / berita rekayasa } \\
\text { - Menerima pesan ancaman / makian }\end{array}$ \\
\hline $\begin{array}{l}\text { Faktor 5: } \\
\text { Tindakan } \\
\text { cyberbullying } \\
\text { / pelecehan }\end{array}$ & $\begin{array}{l}\text { - Mengirim pesan / konten yang menghina / } \\
\text { mempermalukan orang lain } \\
\text { - Mengirim komentar kasar / makian } \\
\text { - Berbagi konten yang merusak reputasi atau } \\
\text { mempermaluan orang lain } \\
\text { - Membuntuti (stalking) akun orang lain }\end{array}$ \\
\hline $\begin{array}{l}\text { Faktor 6: } \\
\text { Orang tak } \\
\text { dikenal }\end{array}$ & 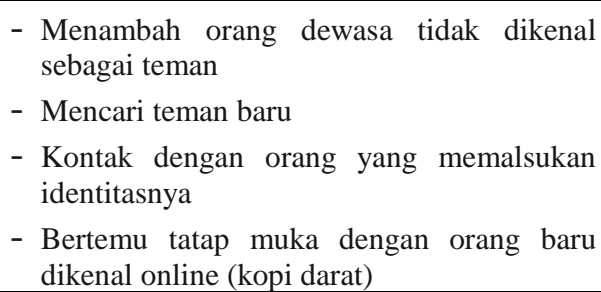 \\
\hline
\end{tabular}

Tabel 4 dan tabel 5 menunjukkan bahwa faktor hasil dari rotasi Varimax membuat bercampur dan terpecahnya item-item (indikator-indikator) dari klasifikasi yang dibuat oleh Livingstone (2014) dan Hasebrink et.al (2009). Misalnya, untuk dimensi (faktor) ke-1 yaitu tindakan berisiko terdiri dari indikatorindikator yang berasal dari risiko kontak (contact risk) dan risiko tindakan (conduct risk). Sebaliknya, klasifikasi risiko konten (content risk) terpecah menjadi tiga dimensi (faktor) yaitu menjadi dimensi nilai / informasi menyesatkan, dimensi pornografi dan dimensi target tindakan berisiko.

Pengujian Eksploratori Analisis Faktor pada penelitian ini dapat menemukan struktur laten dari indikatorindikator pada konstruk risiko online. Ekstraksi dan rotasi dari indikator-indikator tersebut dapat mengungkap faktor-faktor yang sama dan dimensi yang tersembunyi pada konstruk risiko online. Sehingga konstruk ini dapat menjadi variabel risiko online dengan enam dimensi.

\section{SIMPULAN}

Penelitian ini didasari pada kekhawatiran masyarakat pada efek buruk dari penggunaan Internet pada anak dan remaja. Berbagai efek buruk dan potensi dampak penggunaan Internet pada anak dan remaja disebut risiko online. Konstruk risiko online pada penelitian-penelitian sebelumnya diklasifikasikan menjadi 3 dimensi yaitu risiko kontak (content risk), risiko kontak (contact risk) dan risiko tindakan(conduct risk), dimana ketiga dimensi ini hasil klasifikasi berdasarkan studi kualitatif.

Konstruk risiko online ini sudah banyak digunakan untuk meneliti berbagai risiko negatif yang dialami secara tidak sengaja dan yang dilakukan secara sengaja oleh anak dan remaja. Akan tetapi dimensi dan indikator dari konstruk ini belum pernah diuji secara statistik untuk memperoleh jumlah faktor yang tepat yang kemudian dapat dijadikan dimensi dari variabel risiko online.

Uji eksploratori analisis faktor yang dilakukan pada penelitian ini menunjukkan hasil bahwa keseluruhan 33 item pernyataan layak untuk dijadikan indikator karena memiliki koefisien korelasi anti-image yang baik. Dari ekstraksi dan rotasi faktor dihasilkan 6 kelompok faktor dengan nilai kumulatif varians sebesar $69.557 \%$, nilai ini cukup baik karena total varians yang dapat dijelaskan melebih $50 \%$. Enam faktor yang 
dihasilkan ini dapat dijadikan dimensi dari variabel risiko online. Maka, dimensi dari variabel risiko online adalah (1) Tindakan berisiko; (2) Nilai \& informasi menyesatkan; (3) Pornografi; (4) Target dari tindakan berisiko; (5) Perundungan dan pelecehan; (6) Orang tidak dikenal.

Berdasarkan hasil tersebut, maka penelitian ini dapat menemukan dimensi-dimensi untuk variabel risiko online dan membangun skala risiko online untuk penelitian di Indonesia. Akan tetapi perlu dilakukan penelitian lanjutan dengan menggunakan sampel yang lebih banyak dan dari populasi yang lebih luas.

\section{Daftar Pustaka}

Bosch, T. E. (2009). Using online social networking for teaching and learning: Facebook use at the University of Cape Town. Communicatio, 35(2), 185-200. https://doi.org/10.1080/02500160903250648

Cho, C.-H., \& Cheon, H. J. (2005). Children's Exposure to Negative Internet Content: Effects of Family Context. Journal of Broadcasting \& Electronic Media, 49(4), 488-509. https://doi.org/10.1207/s15506878jobem4904

Hasebrink, U., Livingstone, S., Haddon, L., \& Olafsson, K. (2009). Comparing children's online opportunities and risks across Europe: Cross-national comparisons for EU Kids Online. London. https://doi.org/10.1080/17482790701532050

Juditha, C. (2011). Hubungan Penggunaan Situs Di Kota Makassar the Relationship Between the Use of Facebook and Teenegers' Behavior in Makassar, 13(1).

Karman. (2012). Pola Penggunaan Media Digital di Kalangan Anak dan Remaja (Kasus di Kota Jayapura Propinsi Papua). Jurnal Penelitian Pos Dan Informatika, 2(1), 35-50.

Livingstone, S. (2011). Internet, Children, and Youth. In The Handbook of Internet Studies (pp. 348-368). Oxford, UK: Wiley-Blackwell. https://doi.org/10.1002/9781444314861.ch16

Livingstone, S., \& Helsper, E. (2013). Children, internet and risk in comparative perspective. Journal of Children and Media, (May 2014), 1-8. https://doi.org/10.1080/17482798.2012.739751

Livingstone, S., Kirwil, L., Ponte, C., \& Staksrud, E. (2014). In their own words: What bothers children online? European Journal of Communication, 29(3), 271-288. https://doi.org/10.1177/0267323114521045

Livingstone, S., Mascheroni, G., \& Staksrud, E. (2015). Developing a framework for researching children 's online risks and opportunities in Europe.

Park, H. S., Dailey, R., \& Lemus, D. (2002). The Use of Exploratory Factor Analysis and Principal Components Analysis in Communication Research. Human Communication Research, 28(4), 562-577. https://doi.org/10.1093/hcr/28.4.562

Qomariyah, A. (2009). Perilaku Penggunaan Internet pada Kalangan Remaja di Perkotaan. Fakultas Ilmu Sosial Dan Ilmu Politik, Universitas Airlangga.

Setiawan, A. B. (2011). Penanggulangan Dampak Negatif Akses Internet Di Pondok Pesantren Melalui Program Internet Sehat. Jurnal Penelitian Komunikasi, 14(2), 99-114.

Staksrud, E., \& Livingstone, S. (2009). Children and online risk: powerless victims or resourceful participants?, 12(3), 364-387. https://doi.org/10.1080/13691180802635455

Ybarra, M. L., Diener-West, M., \& Leaf, P. J. (2007). Examining the Overlap in Internet Harassment and School Bullying: Implications for School Intervention. Journal of Adolescent Health, 41(6 SUPPL.), 42-50. https://doi.org/10.1016/j.jadohealth.2007.09.004 
Warta ISKI

p-ISSN: 0853-4470 - Vol. 01, No. 01 (2018), pp. 63-70

Tabel 4. Faktor Matriks Terotasi

\begin{tabular}{|c|c|c|c|c|c|c|}
\hline \multicolumn{7}{|c|}{ Rotated Factor Matrix $^{a}$} \\
\hline \multirow[t]{2}{*}{ Item } & \multicolumn{6}{|c|}{ Factor } \\
\hline & 1 & 2 & 3 & 4 & 5 & 6 \\
\hline Content1 & & & .725 & & & \\
\hline Content2_ & & & .761 & & & \\
\hline Content3 & & .469 & .595 & & & \\
\hline Content4 & & .721 & & & & \\
\hline Content5 & & .596 & .437 & & & \\
\hline Content6 & & .820 & & & & \\
\hline Content7 & & .618 & & & & \\
\hline Content8 & & .795 & & & & \\
\hline Content9 & & & & .765 & & \\
\hline Content10 & & & & .703 & & \\
\hline Content11 & & & & .744 & & \\
\hline Content12 & & & .586 & & & \\
\hline Contact1 & & & & & & .694 \\
\hline Contact 2 & & & & & & .766 \\
\hline Contact3 & .756 & & & & & \\
\hline Contact4 & .546 & & & .352 & & \\
\hline Contact5 & .720 & & & & & \\
\hline Contact6 & .443 & & & & & .484 \\
\hline Contact7 & .752 & & & & & \\
\hline Contact8 & .592 & & & & & \\
\hline Contact9 & .528 & & & & & \\
\hline Conduct1 & .799 & & & & & \\
\hline Conduct2 & .821 & & & & & \\
\hline Conduct3 & .724 & & & & & \\
\hline Conduct4 & .467 & & .389 & & .571 & \\
\hline Conduct5 & .751 & & & & & \\
\hline Conduct6 & & & .368 & & .606 & \\
\hline Conduct7 & .415 & & .566 & & .421 & \\
\hline Conduct8 & .449 & & & & .567 & \\
\hline Conduct9 & .708 & & & & & \\
\hline Conduct10 & & & & & .704 & .365 \\
\hline Conduct11 & .390 & & & & & .438 \\
\hline Conduct12 & .629 & & & & .390 & \\
\hline
\end{tabular}

Extraction Method: Maximum Likelihood.

Rotation Method: Varimax with Kaiser Normalization.

a. Rotation converged in 7 iterations. 